\title{
Boletopsis nothofagi sp. nov. associated with Nothofagus in the Southern Hemisphere
}

\author{
Jerry A. Cooper', Patrick Leonard ${ }^{2}$ \\ I Landcare Research, PO Box 40, Lincoln, 7640, New Zealand 2 Motueka, New Zealand \\ Corresponding author: Jerry A. Cooper (CooperJ@landcareresearch.co.nz)
}

Academic editor: K. Hosaka | Received 26 January 2012 | Accepted 5 April 2012 | Published 9 April 2012

Citation: Cooper JA, Leonard P (2012) Boletopsis nothofagi sp. nov. associated with Nothofagus in the Southern Hemisphere. MycoKeys 3: 13-22. doi: 10.3897/mycokeys.3.2762

\begin{abstract}
Boletopsis nothofagi sp. nov., an ectomycorrhizal taxon is described from Nothofagus forests in New Zealand. A comparison of available molecular ITS sequences, and morphological data was carried out to confirm the novelty of the taxon. This is the first report of the genus in the Southern Hemisphere.
\end{abstract}

\section{Key words}

Bankeraceae, Boletopsis nothofagi, Nothofagus, New Zealand

\section{Introduction}

A collection of a Boletopsis species was made in 2009 during the annual foray of the Fungal Network of New Zealand (FUNNZ), at the Orongorongo Valley in the Rimutaka Forest Park east of Wellington, North Island, New Zealand. The material was initially thought to be sterile but subsequent examination showed a few spores with the characteristic thelephoroid morphology of Boletopsis. A subsequent collection in 2010 from South Island and re-collection of material at the North Island site provided more fertile material and is the basis for this description of a new species. This appears to be the first record of the genus in the Southern Hemisphere.

Boletopsis is a genus of ectomycorrhizal, stipitate, poroid fungi phylogenetically related to the hydnoid (toothed) genera Phellodon, Hydnellum, Bankera and Sarcodon and placed in the Bankeraceae (Kirk et al. 2008). Four species are currently recognised in the subgenus Boletopsis (Stalpers 1993; Watling and Milne 2006); B. leucomelaena 
(Pers.) Fayod, the type of the genus, B. grisea (Peck) Bond. \& Sing., B. smithii K. Harrison and B. perplexa Watling \& J. Milne. Boletopsis leucomelaena and B. grised are widely distributed across North America, Europe and Asia, but are nowhere common (Gilbertson 1986). Boletopsis leucomelaena is usually associated with Picea, whereas $B$. grisea and $B$. perplexa are associated with Pinus, but there are records of these species associated with hardwoods. The ectomycorrhizal association of $B$. smithii is unknown. Recent molecular data supports the existence of additional taxa in North America (Watling and Milne 2008). Boletopsis grisea has also been reported from oak dominated cloud forest in Costa Rica and this represents the most southerly record of Boletopsis subgenus Boletopsis to date (Mata and Ryvarden 2007). Two other species, B. atrata Ryvarden and B. subcitrina Corner are pleuropodal, without inflated hyphae, and possess spores with small warts or spines. These species were segregated into Boletopsis subgenus Boletopsina (Stalpers, 1993). Boletopsis subcitrina subsequently formed the basis of a new genus Corneroporus (Hattori, 2001) and it seems likely this group is more distantly related to $B$. leucomelaena than the remaining four accepted species.

\section{Methods}

DNA was extracted from dried herbarium material of the collection PDD96007 using REDExtract-N-Amp Plant PCR Kits (Sigma, USA). The tissue was ground in extraction buffer with a plastic pestle in the Eppendorf tube, then DNA extraction and PCR were carried out following the manufacturer's instructions. The extract was sequenced for the rRNA loci ITS1+5.8+ITS2 and LSU following the methods of (Johnston and Park 2005). Primers were ITS1F and ITS4 for the ITS region and LR0R and LR6 for LSU (Gardes and Bruns 1993). The chromatographs were assembled using Geneious (Drummond et al. 2011). Existing sequences were downloaded from GenBank for Boletopsis species, related New Zealand material and selected sequences of members of the Bankeraceae from other parts of the world (Table 1). Few LSU sequences are available for Boletopsis. This study focussed on ITS sequences resulting from an analysis of the relationships between B. grisea, B. leucomelaena and B. perplexa (Watling and Milne 2008).

Data exchange between applications was facilitated using Alter (Glez-Peña et al. 2010). Sequence alignment was carried using MAFFT (Katoh et al. 2002) within Geneious using the G-INS-i algorithm. Gblocks (Castersana 2000) was used to eliminate poorly aligned segments, with the number of contiguous conserved positions set to 8 , the minimum block set to 10 , and allowed gap positions to half, resulting in an alignment of 493 bases. The alignment was analysed by Jmodeltest (Posada 2008). A best-fit model of nucleotide substitution of $G T R+G$ was proposed by jmodeltest. Phylogenetic analyses were performed MrBayes v3.2 (Huelsenbeck and Ronquist 2001) using the recommended model with two sets of four chains, one cold and three heated, with a chain temperature of 0.2. A sequence of Piptoporus betulinus was selected as an outgroup. All prior probabilities were left on default values. The model was run with a sampling fre- 
Table I. Sequences considered in the analysis.

\begin{tabular}{|c|c|c|c|c|c|}
\hline \begin{tabular}{l|} 
GenBank \\
Accession \\
Numbers \\
\end{tabular} & Taxon & Collection & Country & Host & Notes \\
\hline AF438567 & \begin{tabular}{|l|} 
Boletopsis \\
Leucomelaena
\end{tabular} & & Korea & $?$ & Without ITS2 \\
\hline DQ408766 & Boletopsis sp. & $\begin{array}{l}\text { Holden } \\
150627\end{array}$ & UK & Pinus sylvestris & $\begin{array}{l}=B . \text { perplexa in Watling and } \\
\text { Milne } 2008\end{array}$ \\
\hline DQ408767 & Boletopsis sp. & Wat. 28788 & UK & Pinus sylvestris & $\begin{array}{l}=B \cdot \text { perplexa in Watling } \\
\text { and Milne 2008, } \equiv \text { Holden } \\
077897\end{array}$ \\
\hline DQ408768 & Boletopsis grisea & $\begin{array}{l}\text { Kytovuori 94- } \\
1247\end{array}$ & Finland & Pinus sylvestris & $\begin{array}{l}\equiv \text { Rec227607 see Watling } \\
\text { and Milne } 2008\end{array}$ \\
\hline DQ408769 & Boletopsis grisea & Niemela 6166 & Finland & Pinus sylvestris & $\begin{array}{l}\equiv \text { Rec227608 see Watling and } \\
\text { Milne } 2008\end{array}$ \\
\hline DQ408770 & Boletopsis grisea & Palmen Aug01 & Finland & Pinus sylvestris & $\begin{array}{l}\text { Partial ITS1. =Rec227609 } \\
\text { see Watling and Milne } 2008 \text {, } \\
\text { duplicated as EF457900 B. sp. }\end{array}$ \\
\hline DQ408771 & $\begin{array}{l}\text { Boletopsis } \\
\text { Leucomelaena }\end{array}$ & Niemela 7749 & Finland & Picea sp. & \\
\hline DQ484064 & \begin{tabular}{|l|} 
Boletopsis \\
leucomelaena
\end{tabular} & $\begin{array}{l}\text { PBM 2678/ } \\
\text { AFTOL } 1527\end{array}$ & USA & & \\
\hline EF457898 & Boletopsis sp. & Rec227649 & USA & $?$ & \\
\hline EF457899 & Boletopsis grisea & $\operatorname{Rec} 227658$ & USA & $\begin{array}{l}\text { Tsuga } \\
\text { canadensis }\end{array}$ & \\
\hline EF457900 & Boletopsis sp. & $\operatorname{Rec} 227652$ & USA & $?$ & $\begin{array}{l}\text { Short sequence. Duplicate } \\
\text { reference to Rec } 227609 \text { as } B . \\
\text { grisea see Watling and Milne } \\
2008 \text {, }\end{array}$ \\
\hline EF457901 & Boletopsis grisea & $\operatorname{Rec} 227653$ & USA & ? & $\begin{array}{l}=\text { Rec227652? see Watling } \\
\text { and Milne } 2008\end{array}$ \\
\hline EF457902 & Boletopsis grisea & $\operatorname{Rec} 227659$ & USA & Pinus sylvestris & $\begin{array}{l}=\text { Rec227653? see Watling } \\
\text { and Milne } 2008\end{array}$ \\
\hline EF457903 & Boletopsis grisea & $\operatorname{Rec} 227656$ & USA & Pinus contorta & \\
\hline EU622325 & Boletopsis sp. & SL23 & UK? & $?$ & \\
\hline FJ845401 & $\begin{array}{l}\text { Boletopsis } \\
\text { subsquamosa }\end{array}$ & SMI350 & USA? & ? & $\begin{array}{l}=B . \text { grisea see Watling and } \\
\text { Milne } 2008\end{array}$ \\
\hline AY569026 & $\begin{array}{l}\text { Hydnellum } \\
\text { cumulatum }\end{array}$ & SEW 69 & USA & Tsuga & \\
\hline GU222291 & $\begin{array}{l}\text { Phellodon } \\
\text { sinclairii }\end{array}$ & PDD89028 & $\mathrm{NZ}$ & Nothofagus & \\
\hline GU222318 & Phellodon sp. & PDD89898 & $\mathrm{NZ}$ & $\begin{array}{l}\text { Nothofagus } \\
\text { fusca }\end{array}$ & \\
\hline GU222316 & Phellodon sp. & PDD89880 & $\mathrm{NZ}$ & Nothofagus & \\
\hline GQ267479 & Pseudotomentella & K98C35T239 & $\mathrm{NZ}$ & Pinus radiata & \\
\hline GQ267480 & $\begin{array}{l}\text { Pseudotomentella } \\
\text { tristis }\end{array}$ & K91C38T363 & $\mathrm{NZ}$ & Pinus radiata & \\
\hline
\end{tabular}




\begin{tabular}{|c|c|c|c|c|c|}
\hline $\begin{array}{c}\text { GenBank } \\
\text { Accession } \\
\text { Numbers } \\
\end{array}$ & Taxon & Collection & Country & Host & Notes \\
\hline FJ845438 & \begin{tabular}{|l} 
Sarcodon \\
imbricatus
\end{tabular} & SMI347 & Canada & Pinus? & \\
\hline GQ267491 & Tomentella sp. & K80C37T323 & $\mathrm{NZ}$ & Pinus radiata & \\
\hline HQ533015 & Tomentellopsis sp. & PDD95789 & $\mathrm{NZ}$ & $\begin{array}{l}\text { Nothofagus } \\
\text { solandri }\end{array}$ & $\begin{array}{l}\text { T. cf. zygodesmoides, with pale } \\
\text { brown spores }\end{array}$ \\
\hline JQ417193 & $\begin{array}{l}\text { Boletopsis } \\
\text { nothofagi }\end{array}$ & PD96007 & NZ & $\begin{array}{l}\text { Nothofagus } \\
\text { fusca }\end{array}$ & South Island, St Arnaud \\
\hline
\end{tabular}

quency of 500 until the split-deviation frequency had fallen below 0.01 , ca 1.2 million iterations. The results were examined to ensure good Metropolis coupling of chains and convergence statistics using Tracer (Rambaut and Drummond 2009). The first $25 \%$ of trees were removed in constructing a 50\% majority rule consensus phylogram.

\section{Results}

Figure 1 shows the results of the phylogenetic analysis. The species concepts $B$. grisea and B. perplexa are supported. Boletopsis sp. (SL23), B. subsquamosa (SMI350), and Boletopsis sp. (Rec227652) are also referable to B. perplexa. The latter collections confirm the presence of this taxon in North America, as suggested by (Watling and Milne 2008). A consensus concept of $B$. leucomelaena is less well supported by these preliminary data with the collections appearing separately in the analysis. It is possible the current use of the name $B$. leucomelaena represents multiple cryptic taxa; it is reported as occurring in widely separate geographic regions and with differing ectomycorrhizal hosts. A similar situation was recently demonstrated in the case of European species of related Hydnellum and Phellodon (Ainsworth et al. 2010). Boletopsis nothofagi is clearly supported as a new taxon differing in 22 sites relative to B. leucomelaena (AFTOL, DQ484064) and 18 sites relative to B. leucomelaena (Niemela, DQ408771).

\section{Discussion}

The presence of $B$. nothofagi in New Zealand beech forests appears to have been overlooked despite a long history of the study of similar fungi in New Zealand (Cunningham 1958) (Maas Geesteranus 1971). This suggests B. nothofagi is a relatively rare (or rarely fruiting) indigenous member of the New Zealand ectomycorrhizal beech forest mycota. In addition no records of Boletopsis have been traced for any localities of naturally occurring Nothofagus forests in Australia, New Caledonia, New Guinea or South America. An alternative explanation for the presence of B. nothofagi in New Zealand is 


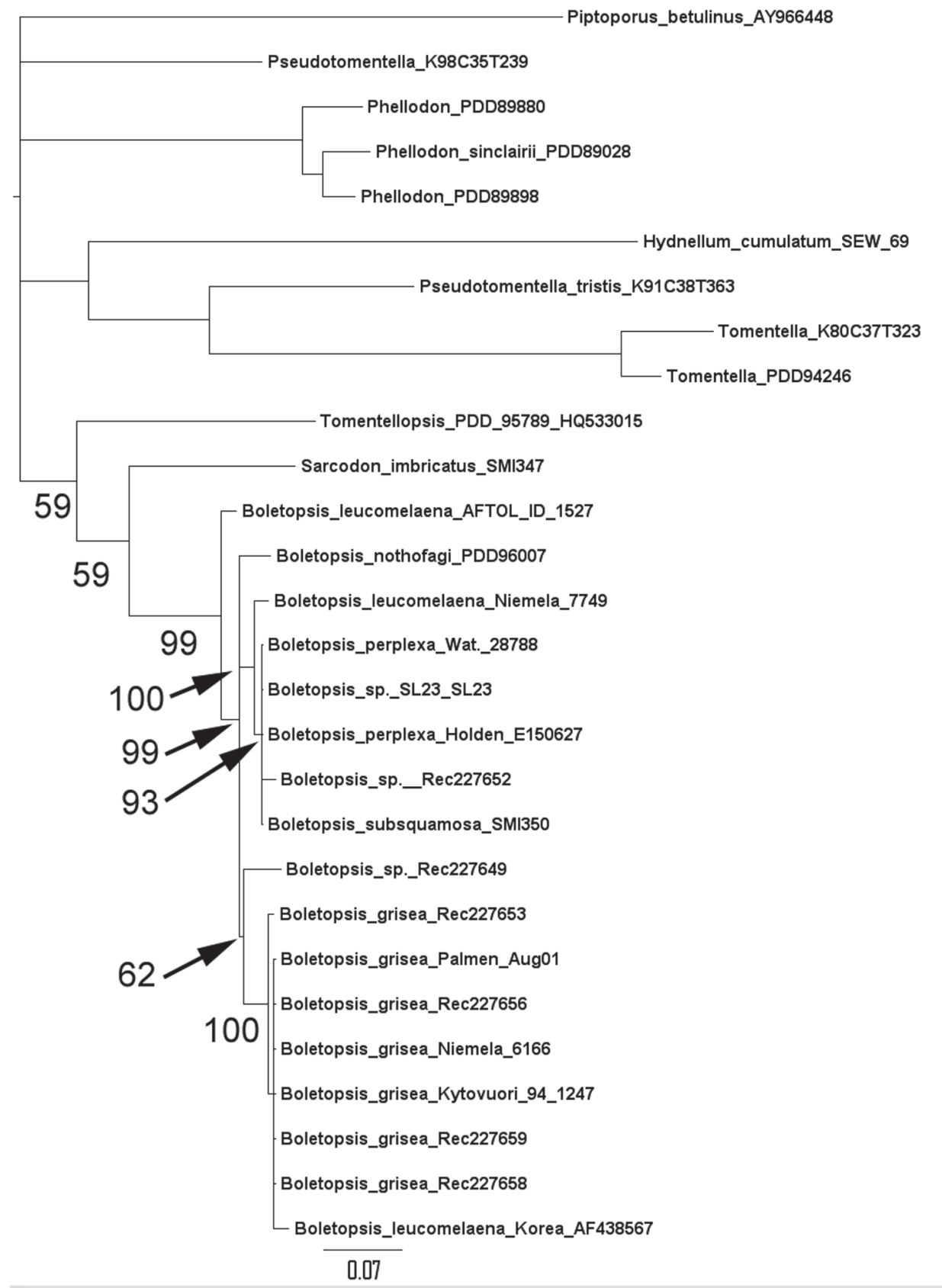

Figure I. Baysian consensus phylogram, showing posterior probability, scale = substitutions per site

as a recent introduction of a species that usually has a different ectomycorrhizal host. Such introductions into New Zealand beech forests have occurred at least once in the case of Amanita muscaria (Johnston et al. 2008). 
The absence of previous records of this recognisable species combined with the wide separation of the two currently known sites indicate that Boletopsis nothofagi is most likely a rare indigenous member of the New Zealand beech forest mycota. Its conservation status in New Zealand requires further investigation considering the status of other members of the family elsewhere in the world. For example many hydnoid members of the family are threatened in Europe due to a variety of causes (Arnolds 2010). Many of these species are listed on European national red-data lists of fungi (Dahlberg and Mueller 2011). Boletopsis grisea is currently designated as threatened on five national lists and is subject to a number of management plans (Anon 1998-2011).

\section{Taxonomic treatment}

\section{Boletopsis nothofagi J.A. Cooper \& P. Leonard, sp. nov.}

Registration Identifier: IndexFungorum IF550039

http://species-id.net/wiki/Boletopsis_nothofagi

Holotype: PDD96007

Description. Basidiomes fasiculate, occasionally solitary, centrally stipitate, tough and fibrous. Pileus more or less convex, $10-80 \mathrm{~mm}$ diameter $\times 5-20 \mathrm{~mm}$ high, becoming undulate and edge somewhat incurved when young, smooth to finely fibrillose, grey [1D1, 1E1] (Kornerup and Wanscher 1989), weakly nigrescent when bruised and eventually becoming black. Stipe stuffed, clavate or cylindrical, 20-60 mm in length $\times 10-25 \mathrm{~mm}$ diameter, narrowing slightly at base and apex, smooth, dry, concolorous with pileus and darkening where bruised. Hymenial layer white 1-2 mm deep, bruising tan, pores angular, 2-3 per mm, drying pinkish tan, sometimes with lacerate edges. Pore layer extending slightly down the stipe and clearly delineated. Smell of dried material weakly of fenugreek, taste slightly acidic. Pileus immediately black in $\mathrm{KOH}$, pigment leaching olivaceous black into white absorbent paper. Spore print not obtained.

Hyphal system monomitic. Pileus with a differentiated pileipellis consisting of a cutis, hyphae to $2 \mu \mathrm{m}$ diameter, with brown plasmatic pigment, hyphal surface covered in small amorphous granular material becoming dark green in $\mathrm{KOH}$ and dispersing into medium. Subcutis with inflated gloeoplerous-like hyphae, thin-walled, to $6 \mu \mathrm{m}$ diameter, clamped. Basidia pleurobasidial, cylindrical to clavate 5-10 × 20-30 $\mu \mathrm{m}$, 4-spored, with basal clamp. Pores with fringe of slender clavate cystidia-like elements to $80 \times 4 \mu \mathrm{m}$. Spores very pale tan, thin-walled, not dextrinoid or amyloid, non-cyanophilous, flat-topped tuberculate, with a narrowed waist. Spores dimensions are of a bounding rectangle encompassing maximum length and width of each spore. Length $\mu=5.3 \mu \mathrm{m}, \sigma=0.5$, width $\mu=4.1 \mu \mathrm{m}, \sigma=0.5$, Q $\mu=1.35, \sigma=0.2$ (combined statistics of measurement of 4, 13,26, 20 spores from three fruiting bodies of the three collections).

Distribution. North and South Islands of New Zealand

Ecology. ectomycorrhizal in southern beech (Nothofagus) forests and so far found only in association with Nothofagus fusca. 


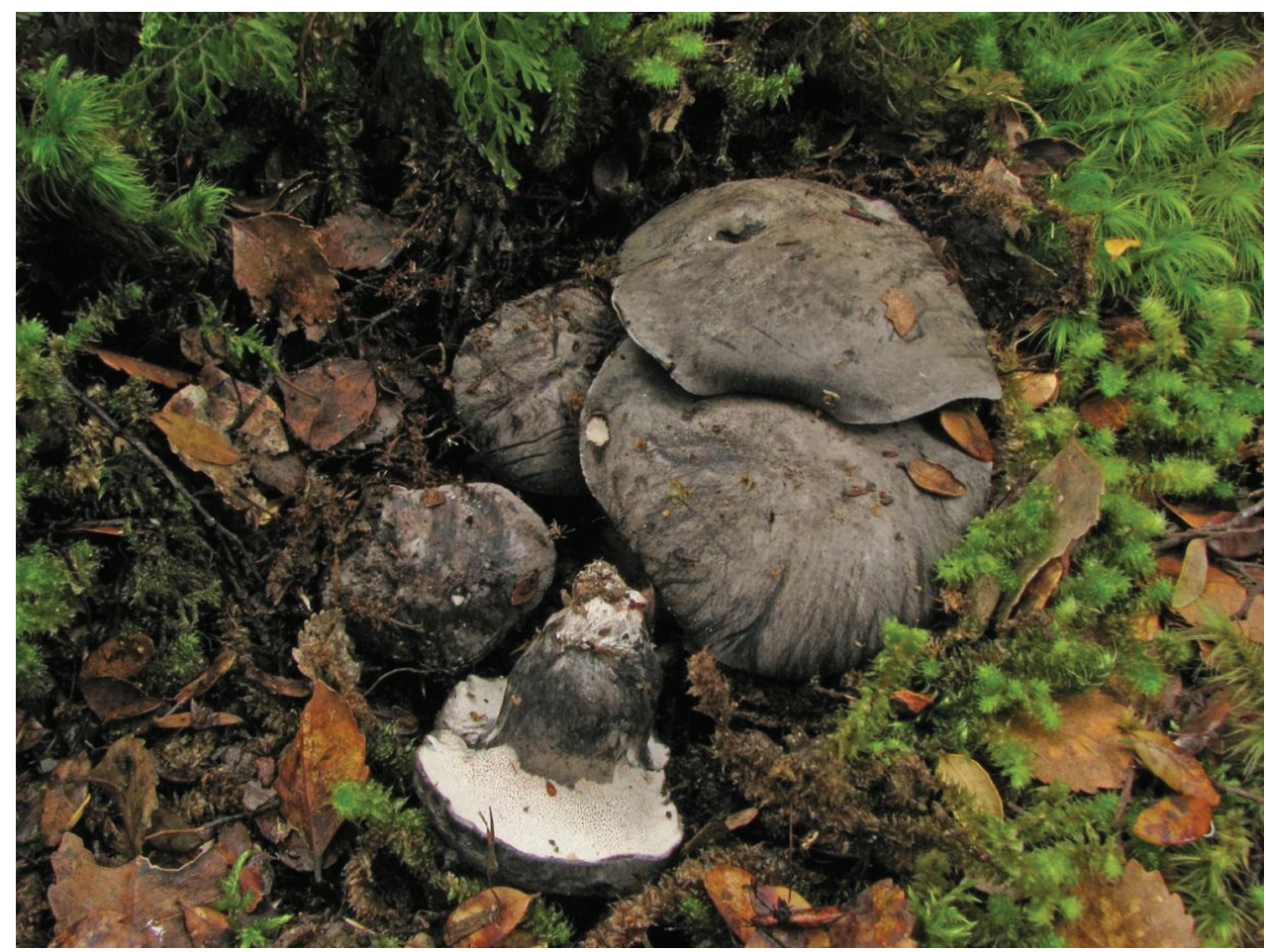

Figure 2. Basidiomes in natural habitat (PDD96007).

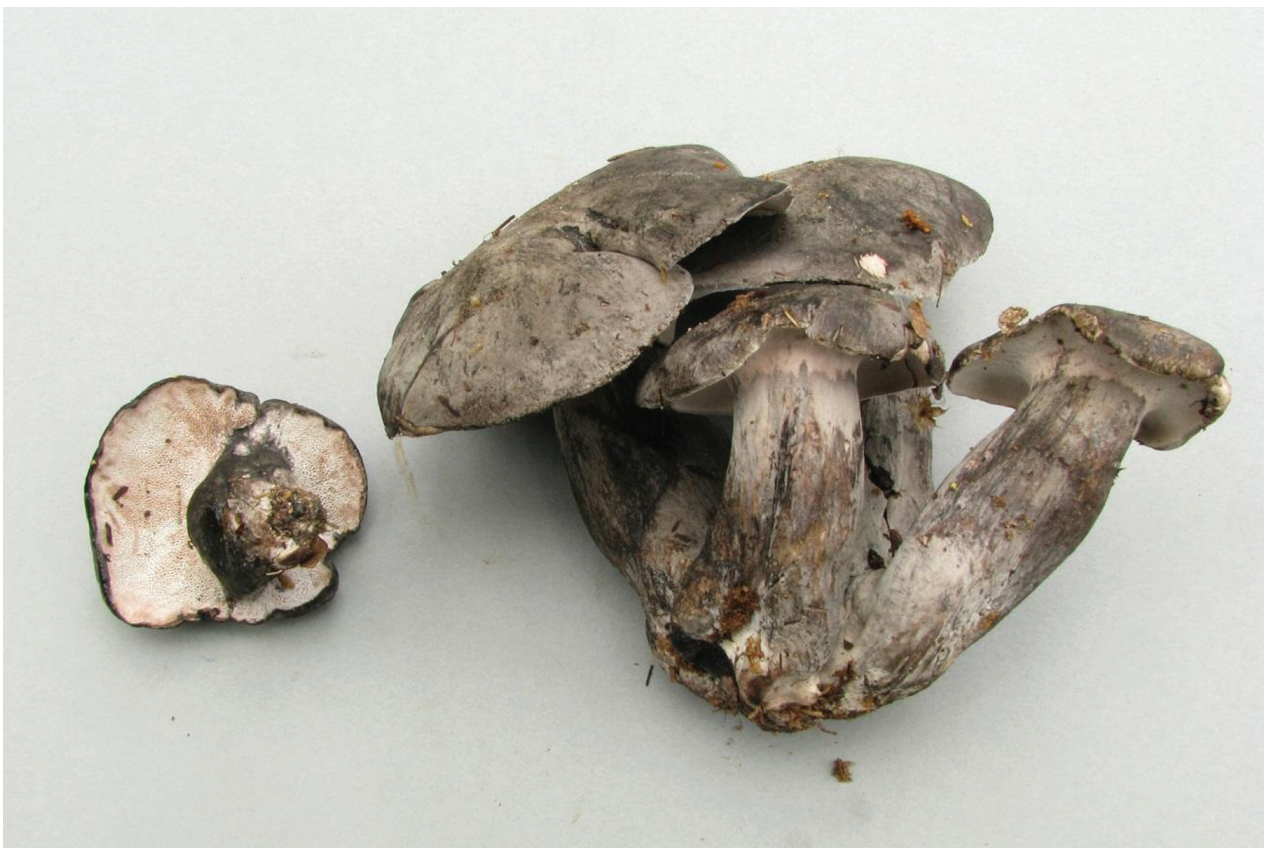

Figure 3. Basidiomes (PDD96007). 

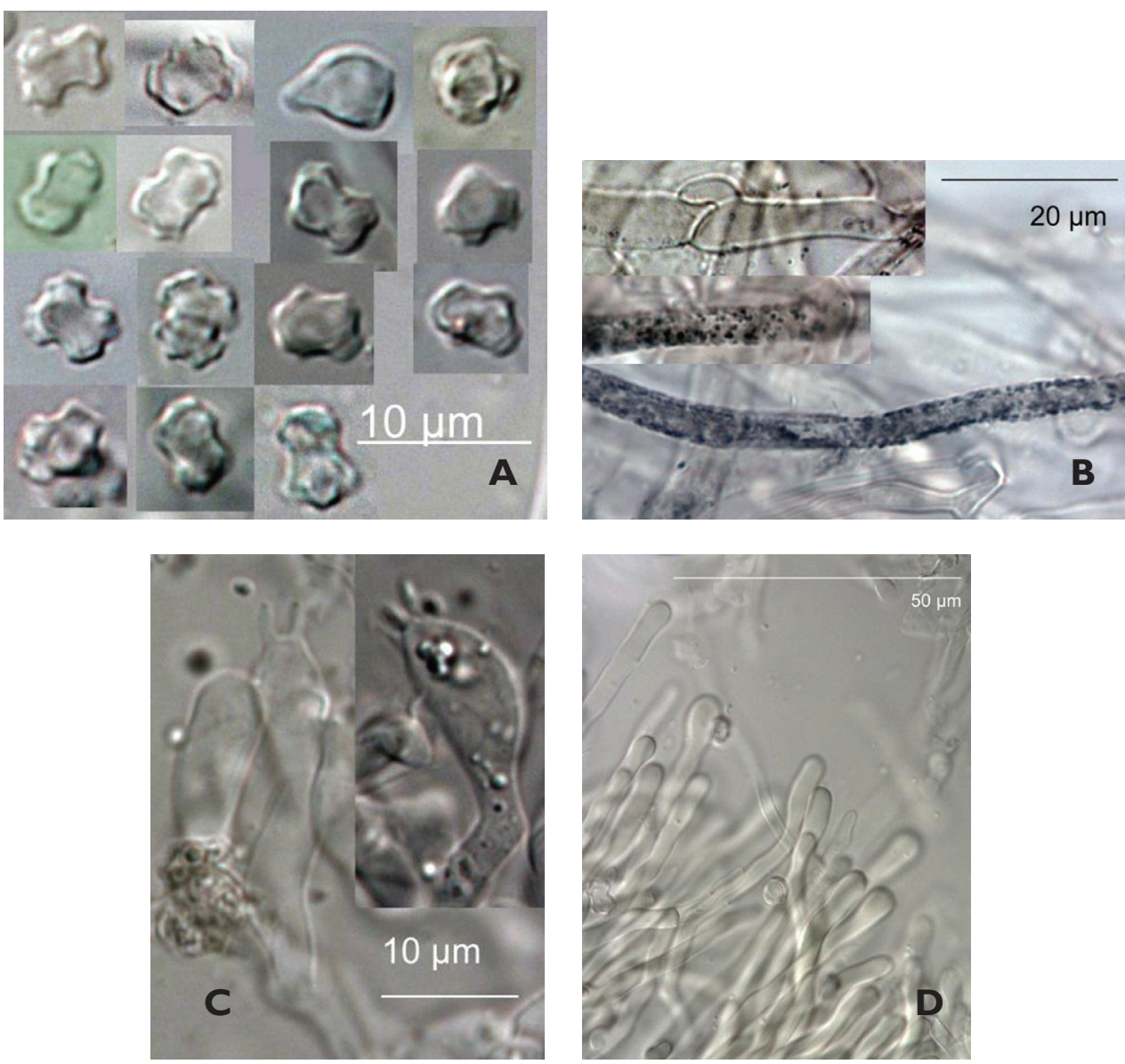

Figure 4. Microscopic Details. A Spores in Melzers (PDD96012) B Cap hyphae showing clamps and granules in $\mathrm{KOH}$ (PDD96012) C Basidia in $\mathrm{KOH}$ (PDD96012) D Cystidia-like elements in $\mathrm{KOH}$ (PDD96012)

Etymology. nothofagi for its ectomycorrhizal association with Nothofagus.

Conservation status. Although there are no data on the stability of the population size or historical changes in distribution of this species, it is likely to be naturally uncommon according to the New Zealand Threat Classification System (Townsend et al. 2008).

Holotype. NEW ZEALAND, North Island, Rimutaka Forest Park (under Nothofagus fusca), NZMG: 2671550E, 5982715N, $2^{\text {nd }}$ May 201, D. Batchelor \& P. Leonard, PDD96007 (PL3511)

Other specimens examined. New Zealand, North Island, Rimutaka Forest Park (under Nothofagus fusca), NZMG: 2671550E, 5982715N, 15 ${ }^{\text {th }}$ May 2009, T. Lebel, PDD95529 (JAC11078). West Bay, St Arnaud (Nothofagus fusca), South Island, NZMG: $1586280 E$, 5372097N, $11^{\text {th }}$ May 2010, S. Kerr \& P. Leonard, PDD96012. 
Discussion. Boletopsis nothofagi differs from described species in the more elongate spores with a narrow central waist, granular extra-cellular material becoming green in $\mathrm{KOH}$ and habitat in Nothofagus forests (Niemala and Saarenoska 1989; Harrison 1975; Watling and Milne 2006).

\section{Acknowledgements}

Thanks go to Teresa Lebel who discovered the original collection and made extensive notes of PDD95529, and to Shirley Kerr who discovered the second collection. Dukchul Park of Landcare Research carried out DNA extraction and sequence generation. This work was supported by the New Zealand Ministry of Science and Innovation.

\section{References}

Ainsworth A, Parfitt B, Rogers H, Boddy L (2010) Cryptic taxa within European species of Hydnellum and Phellodon revealed by combined molecular and morphological analysis. Fungal Ecology: 65-80. doi: 10.1016/j.funeco.2009.07.001

Anon (2011) European Council for the Conservation of Fungi. Available at: http://www.wsl. ch/eccf/redlists-en.ehtml [Accessed 2011]

Arnolds E (2010) The fate of hydnoid fungi in The Netherlands and Northwestern Europe. Fungal Ecology 3: 81-88. doi: 10.1016/j.funeco.2009.05.005

Castersana J (2000) Selection of conserved blocks from multiple alignments for their use in phylogenetic analysis. Molecular Biology and Evolution 17: 540-552.

Cunningham G (1958) Hydnaceae of New Zealand. Part I. The pileate genera Beenakia, Dentinum, Hericium, Hydnum, Phellodon and Steccherinum. Transactions of the Royal Society of New Zealand 85: 585-601.

Dahlberg A, Mueller G (2011) Applying IUCN red-listing criteria for assessing and reporting on the conservation status of fungal species. Fungal Ecology 4: 147-162. doi: 10.1016/j. funeco.2010.11.001

Drummond AJ, Ashton B, Buxton S, Cheung M, Cooper A, Duran C, Field M, Heled J, Kearse M, Markowitz S, Moir R, Stones-Havas S, Sturrock S, Thierer T, Wilson A (2011) Geneious v5.4. Available from: http://www.geneious.com/

Gardes M, Bruns T (1993) ITS primers with enhanced specificity for basidiomycetes-application to the identification of mycorrhizae and rusts. Molecular Ecology 2: 113-118. doi: 10.1111/j.1365-294X.1993.tb00005.x

Gilbertson RL, Ryvarden L (1986) North American Polypores - Volume 1. Fungiflora, Oslo, 433.

Glez-Peña D, Gómez-Blanco D, Reboiro-Jato M, Fdez-Riverola F, Posada D (2010) ALTER: program-oriented format conversion of DNA and protein alignments. Nucleic Acids Research 38(2): 14-18. doi: 10.1093/nar/gkq321 
Harrison K (1975) A New Species of Boletopsis. Beihefte Nova Hedwigia 51: 119-121.

Hattori T (2001) Type studies of the polypores described by EJH Corner from Asia and West Pacific Areas III Species described in Trichaptum, Albatrellus, Boletopsis, Diacanthodes, Elmerina, Fomitopsis and Gloeoporus. Mycoscience 42: 423-431. doi: 10.1007/BF02464338

Huelsenbeck J, Ronquist F (2001) MrBayes: Bayesian inference of phylogenetic trees. Bioinformatics 17: 754-755. doi: 10.1093/bioinformatics/17.8.754

Johnston P, Park D (2005) Chlorociboria (Fungi, Helotiales) in New Zealand. New Zealand Journal of Botany 43: 679-719. doi: 10.1080/0028825X.2005.9512985

Johnston PR, Buchanan PK, Mortimer S, Leathwick J (2008) Fungal invaders. Australasian Mycological Newsletter 17: 48-52.

Katoh K, Misawa K, Kuma K, Miyata T (2002) MAFFT: a novel method for rapid multiple sequence alignment based on fast Fourier transform. Nucleic Acids Research 30: 30593066. doi: 10.1093/nar/gkf436

Kirk PM, Cannon PF, Minter DW, Stalpers JA (2008) Dictionary of the Fungi. CABI, Wallingford, 784.

Kornerup A, Wanscher J (1989) Methuen Handbook of Colour. Eyre Methuen, London, 252.

Maas Geesteranus R (1971) Hydnaceous fungi of the eastern Old World (Verhandelingen der Koninklijke Nederlandse Akademie van Wetenschappen. Afd. Natuurkunde). Royal Netherlands Academy, Volume 60.

Mata M, Ryvarden L (2007) Studies in Neotropical polypores 24. New and interesting species from Costa Rica. Synopsis Fungorum 23: 51-55.

Niemala T, Saarenoska T (1989) On Fennoscandian polypores 10. Boletopsis leucomelaena and B. grisea described and llustrated. Karstenia 29: 12-28.

Posada D (2008) jModelTest: phylogenetic model averaging. Molecular Biology and Evolution 25: 1253-1256. doi: 10.1093/molbev/msn083

Rambaut A, Drummond A (2009) Tracer v1.5. Available from http://beast.bio.ed.ac.uk/Tracer

Stalpers J (1993) The Aphyllophoraceous fungi I, Keys to the species of the Thelephorales. Studies in Mycology 35: 1-168.

Townsend A (2008) New Zealand Threat Classification System Manual. New Zealand Department of Conservation, 35 .

Watling R, Milne J (2006) A new species of Boletopsis associated with Pinus sylvestris L in Scotland. Botanical Journal of Scotland 58: 81-92. doi: 10.1080/03746600608685110

Watling R, Milne J (2008) The identity of European and North American Boletopsis spp. (Basidiomycota; Thelephorales, Boletopsidaceae). North American Fungi 3(7): 5-15. doi: $10.2509 /$ naf2008.003.0072 